\title{
Effect of P2X4R on airway inflammation and airway remodeling in allergic airway challenge in mice
}

\author{
HONGXIA CHEN $^{1 *}$, QINGQING XIA ${ }^{2 *}$, XIAOQIAN FENG $^{1}$, FANGYUAN CAO $^{1}$, \\ HANG $\mathrm{YU}^{3}$, YINLI SONG ${ }^{1}$ and XIUQIN NI ${ }^{2}$ \\ Departments of ${ }^{1}$ Pathology, ${ }^{2}$ Anatomy and ${ }^{3}$ Physiology, Harbin Medical University-Daqing, \\ Daqing, Heilongjiang 163319, P.R. China
}

Received January 21, 2015; Accepted October 29, 2015

DOI: $10.3892 / \mathrm{mmr} .2015 .4622$

\begin{abstract}
P2X4 receptor (P2X4R) is the most widely expressed subtype of the P2XRs in the purinergic receptor family. Adenosine triphosphate (ATP), a ligand for this receptor, has been implicated in the pathogenesis of asthma. ATP-P2X4R signaling is involved in pulmonary vascular remodeling, and in the proliferation and differentiation of airway and alveolar epithelial cell lines. However, the role of P2X4R in asthma remains to be elucidated. This aim of the present study was to investigate the effects of P2X4R in a murine experimental asthma model. The asthmatic model was established by the inhalation of ovalbumin (OVA) in BALB/c mice. The mice were treated with $\mathrm{P} 2 \mathrm{X} 4 \mathrm{R}$-specific agonists and antagonists to investigate the role of this receptor in vivo. Pathological changes in the bronchi and lung tissues were examined using hematoxylin and eosin staining, Masson's trichrome staining and Alcian blue staining. The inflammatory cells in the bronchoalveolar lavage fluid were counted, and the expression levels of P2X4R, $\alpha$-smooth muscle actin ( $\alpha$-SMA) and proliferating cell nuclear antigen (PCNA) were detected using western blotting. In the OVA-challenged mice, inflammation, infiltration, collagen deposition, mucus production, and the expression levels of P2X4R and PCNA were all increased; however, the expression of $\alpha$-SMA was decreased, compared with the mice in the control group. Whereas treatment with the
\end{abstract}

Correspondence to: Professor Xiuqin Ni, Department of Anatomy, Harbin Medical University-Daqing, 39 Xinyang Road, Daqing, Heilongjiang 163319, P.R. China

E-mail: nxq200285@163.com

Professor Yinli Song, Department Pathology, Harbin Medical University-Daqing, 39 Xinyang Road, Daqing, Heilongjiang 163319, P.R. China

E-mail: syl3127@126.com

${ }^{*}$ Contributed equally

Key words: adenosine triphosphate, $\mathrm{P} 2 \mathrm{X} 4$ receptor, inflammation, asthma, remodeling
P2X4R agonist, ATP, enhanced the allergic reaction, treatment with the P2X4R antagonist, 5-BDBD, attenuated the allergic reaction. The results suggested that ATP-P2X4R signaling may not only contribute to airway inflammation, but it may also contribute to airway remodeling in allergic asthma in mice.

\section{Introduction}

Asthma is a chronic inflammatory airway disease involving several different types of cell. It is considered an allergic disease with characteristic airway inflammation, airway hyper-responsiveness (AHR) and airway remodeling (1-3). At present, anti-inflammatories are the predominant therapeutic option for patients with asthma (4,5). Previous studies (6-8) have shown that airway remodeling results in the progressive loss of lung function. Airway remodeling includes epithelial denudation, subepithelial fibrosis, mucus gland hypertrophy, myofibroblast and smooth muscle cell proliferation, and angiogenesis (9-11). The expression levels of $\alpha$-smooth muscle actin $(\alpha-$ SMA) $(12,13)$ and proliferating cell nuclear antigen (PCNA) $(14,15)$ are indicative of asthmatic cell proliferation.

Adenosine triphosphate (ATP), a key mediator of acute and chronic inflammation, can be released in substantial quantities from various cell types following cellular stress or tissue injury (16-19). Extracellular ATP exerts pro-inflammatory and immunomodulatory effects in the tumor microenvironment by binding to purinergic P2-receptors, which can be subdivided into two families: The G-protein-coupled P2YR (P2Y 1-14) and the ligand-gated ion channel, $\mathrm{P} 2 \mathrm{X}$ receptors (P2XR), which include P2X1-7 (20-22). Data from patient and animal models of allergic bronchial asthma indicate that ATP contributes to the pathophysiology of allergic airway inflammation (16). However, whether ATP-mediated P2X4R signaling is activated in allergic asthma remains to be elucidated.

Among the P2XR subtypes, P2X4R is the most widely expressed (23). $\mathrm{P} 2 \mathrm{X} 4$ receptors are located in immune and non-immune cells, including alveolar epithelial cells, alveolar macrophages, platelets, lymphocytes and mast cells (24-26). $\mathrm{P} 2 \mathrm{X} 4 \mathrm{R}$ can affect $\mathrm{T}$ cell activation via $\mathrm{Ca} 2^{+}$influx. ATP-P2X4R signaling is involved in peripheral nerve injury inflammation, which includes the promotion of the expression levels of interleukin (IL)-1 $\beta$, IL-6 and tumor necrosis factor (TNF)- $\alpha$ via 
mitogen-activated protein kinase activation; indicating that $\mathrm{P} 2 \mathrm{X} 4 \mathrm{R}$ is involved in the immune response to nerve inflammation (27). Several studies have demonstrated that P2X4 receptors are involved in hypersensitivity by acting on prostaglandin E2 (28-30). ATP-P2X4R signaling is also involved in pulmonary vascular remodeling, and in the proliferation and differentiation of airway and alveolar epithelial cell lines in pulmonary hypertension $(31,32)$. However, whether P2X4R signaling is involved in allergic airway inflammation and airway remodeling requires further investigation.

The aim of the present study was to investigate the effects of P2X4R in a murine experimental asthma model and the effects of a P2X4R-specific antagonist, 5-BDBD, on airway inflammation and airway remodeling. Our findings may ultimately lead to the development of novel therapeutic targets for allergic asthma.

\section{Materials and methods}

Chemicals and reagents. Rabbit polyclonal anti-P2X4R primary antibody was purchased from Calbiochem (EMD Millipore, Billerica, MA, USA; cat. no. PC376) and used for western blotting. Mouse monoclonal anti-PCNA primary antibody (cat. no. BM0104) and anti- $\alpha$-SMA primary antibody (cat. no. BM0002) were purchased from Boster Systems, Inc. (Wuhan, China). Mouse monoclonal anti- $\beta$-actin primary antibody (cat. no. TA-09) was purchased from ZSGB Biotechnology, Inc. (Beijing, China). Mouse anti-rabbit (cat. no. sc-2357) and rabbit anti-mouse (cat. no. sc-358914) IgG-horseradish peroxidase-conjugated secondary antibodies were purchased from Santa Cruz Biotechnology Inc. (Santa Cruz, CA, USA). The P2X4R-specific antagonist, 5-BDBD, was obtained from Tocris Bioscience (Bristol, UK). The Masson's trichromatic staining kit and Alcian blue-periodic acid-schiff (AB-PAS) mucosa staining kit were purchased from Fuzhou Maixin Biotechnology, Co., Ltd. (Fuzhou, China). ATP and the P2XR1/2/3/5/7 antagonist, phenyl-isopropyl-amine dopes (PPAD), were all purchased from Sigma-Aldrich (St. Louis, MO, USA). All other reagents were obtained from common commercial sources.

Experimental animals. Pathogen-free female BALB/c mice, aged 6-8 weeks and weighing 18-20 g, were purchased from the Laboratory Animal Research Center (Beijing, China). Mice were maintained under $12 \mathrm{~h}$ light/dark cycles at room temperature, with free access to food and water. All animal experiments and manipulation procedures were approved by the Ethics Committee for Animal Use and Care of Harbin Medical University-Daqing (Daqing, China).

Animal groups and allergic sensitization protocol. A total of $48 \mathrm{BALB} / \mathrm{c}$ mice were randomized into the following five groups: Phosphate-buffered saline (PBS) control group $(n=8)$, OVA group $(n=10)$, ATP group $(n=10)$, PPAD group $(n=10)$ and 5-BDBD group $(n=10)$. In the OVA group, the mice were sensitized to OVA (20 $\mu \mathrm{g}$ per injection), absorbed to $2.0 \mathrm{mg}$ per injection of aluminum hydroxide (Tianjin Fuchen Chemical Reagents Factory, Tianjin, China), by intraperitoneal injection on day 1 . On days 8,15 and 22 , the mice were sensitized again to OCA (10 $\mu \mathrm{g}$ per injection), absorbed to $1.0 \mathrm{mg}$ per injection of aluminum hydroxide, by intraperitoneal injection. From day 23, the mice were exposed, using inhalation aerosols, of 4\% OVA in PBS for 25-30 min, until the onset of bronchial obstruction, daily for 7 days consecutively, according to the methods described by Shen et al (31) and Vanacker et al (32) with modifications. The mice in the ATP, PPAD and 5-BDBD groups were also subjected to OVA sensitization and asthma induction, in the same manner. Intranasal application of $50 \mu 1$ ATP (1 mM) (33), PPAD (0.1 mM) (34) and 5-BDBD (30 $\mu \mathrm{mol}$ ) (35) were performed $3 \mathrm{~h}$ prior to each airway allergen challenge in the ATP, PPAD and 5-BDBD groups, respectively. All treatments were administered daily for 5 days consecutively. Mice in the control group were administered with PBS alone $(0.5 \mathrm{ml})$ by injection, and were challenged with PBS $(20 \mathrm{ml})$. All animals were humanely sacrificed within $24 \mathrm{~h}$ of the final OVA or PBS exposure.

Morphometric analysis. The lungs were fixed in 4\% paraformaldehyde, embedded in paraffin and sectioned at a thickness of $5 \mu \mathrm{m}$. The sections from each animal were stained with hematoxylin and eosin for inflammation, Masson's trichrome staining for collagen-deposition and Alcian blue/periodic acid-Schiff (AB-PAS) staining for the analysis of goblet cell hyperplasia/mucus production. All staining procedures were performed in accordance with the manufacturer's protocol. Pathological changes in the lung and bronchial tissues were observed and images were captured using a BX-60 microscope (Olympus, Tokyo, Japan). The tissues were scored based on the presence of inflammatory cells, using the following scale: Absent (0), rare (1), mild (2), moderate (3) or severe (4). Scoring was performed by an observer in a blinded-manner. Positively stained areas of collagen and mucus in the lung and bronchial tissues were quantified using high-resolution images of individual vessels by image analysis, using a color-recognition algorithm, in Image Pro Plus 6.0 (Media Cybernetics, Inc., Rockville, MD, USA). The results were expressed as the percentage of collagen area or mucus area, compared to the total measured area.

Bronchoalveolar lavage fluid (BALF). Samples of BALF were collected $24 \mathrm{~h}$ following the final challenge, according to previously described methods. The lungs were lavaged with $1.6 \mathrm{ml}$ (0.8 $\mathrm{ml}$ per lavage) of ice-cold PBS via the tracheal cannula. The retrieved volume $(\sim 75-80 \%)$ of the instilled PBS was then centrifuged at $500 \times \mathrm{g}$ at $4^{\circ} \mathrm{C}$ for $5 \mathrm{~min}$. The resultant pellet was washed twice with PBS and was resuspended in $1 \mathrm{ml}$ PBS. The total numbers of cells were counted using a hemocytometer (Bio-Rad Laboratories, Inc., Hercules, CA, USA). Smears of the BALF cells were stained with Wright and Giemsa staining fluid (Beijing Solarbio Science \& Technology Co., Ltd., Beijing, China) for differential cell counting. Using a BX-60 Olympus microscope, the numbers of cells were counted by two independent investigators, in a blinded-manner. A total of $\sim 200$ cells were counted in each of four randomly selected locations.

Western blotting. The lung tissues were homogenized with cold lysis buffer (Beyotime Institute of Biotechnology, Shanghai, China), containing $50 \mathrm{mM}$ Tris (pH 7.4), $150 \mathrm{mM} \mathrm{NaCl}, 1 \%$ Triton X-100, 1 mM EDTA and 2 mM PMSF. Following 
ultrasonication on ice for $5 \mathrm{sec}$ using an FA-25 (Fluko Equipment Shanghai Co., Ltd., Shanghai, China) and centrifugation at $12,500 \mathrm{x} \mathrm{g}$ at $4^{\circ} \mathrm{C}$ for $15 \mathrm{~min}$, the supernatant was collected, and the protein concentration was determined using a Bicinchoninic Acid Protein Assay (Pierce Biotechnology, Inc., Rockford, IL, USA) with bovine serum albumin (Biosharp, Hefei, China) as a standard. Each sample, containing $20 \mu \mathrm{g}$ protein, was separated on $8-10 \%$ SDS-PAGE gels and transferred onto nitrocellulose membranes (EMD Millipore). Following blocking with Tris-buffered saline, containing $20 \mathrm{mM}$ Tris, $150 \mathrm{mM} \mathrm{NaCl}$ (pH 7.6) and $0.1 \%$ Tween 20 , with $5 \%$ nonfat milk at room temperature, the membranes were incubated overnight at $4^{\circ} \mathrm{C}$ with specific antibodies against P2X4R (1:400 dilution), $\alpha-S M A$ (1:500 dilution), PCNA (1:500 dilution) or $\beta$-actin $(1: 1,000$ dilution). This was followed by incubation for $2 \mathrm{~h}$ at room temperature with horseradish peroxidase-conjugated secondary antibodies (1:5,000 dilution). All protein blots were visualized using enhanced chemiluminescence reagents (GE Healthcare Life Sciences). Integrated density values were analyzed using a computerized image analysis system (Fluor Chen 2.0; Olympus Corporation) and were normalized to those of $\beta$-actin.

Statistical analysis. Data were analyzed using SPSS 15.0 software (SPSS, Inc., Chicago, IL, USA). Data are expressed as the mean \pm standard error of the mean. Differences between groups were analyzed using Student's t-test and one-way analysis of variance, followed by Fisher's least significant difference test. $\mathrm{P}<0.05$ was considered to indicate a statistically significant difference.

\section{Results}

OVA-challenge upregulates the protein expression of $P 2 X 4 R$ in mice. The present study performed western blotting to compare the protein expression levels of P2X4R in the lung tissues of the treatment groups (Fig. 1A and B). As shown in Fig. 1, OVA-challenge significantly increased the expression of P2X4R, compared with the control mice.

P2X4R contributes to inflammation of the bronchi and lung tissues in allergic airway challenge in mice. Histological analyses of the tissues of the mice in the OVA group showed more extensive infiltration of inflammatory cells around the bronchioles, blood vessels and alveoli. The airway mucosa showed edema, with bronchiolar wall thickening causing luminal stenosis, suggesting successful establishment of the asthmatic model. In the OVA-challenged mice, treatment with ATP significantly increased OVA-induced inflammation, infiltration, and pathological changes of the bronchi and lung tissues. By contrast, treatment of OVA-challenged mice with PPAD (a P2X1, 2, 3, 5 and 7R antagonist) (36) and 5-BDBD (a P2X4R antagonist) (37) significantly reduced the extent of inflammation and cellular infiltration in the airway. In addition, the pathological changes of the bronchi and lung tissues were milder, compared with the changes found in the asthma group without treatment (Fig. 2A and B).

Cell numbers and differential cell percentages in BALF. The total cell numbers (Fig. 3A) and the percentages of eosinophils and lymphocytes (Fig. 3B) in the BALF from the
A
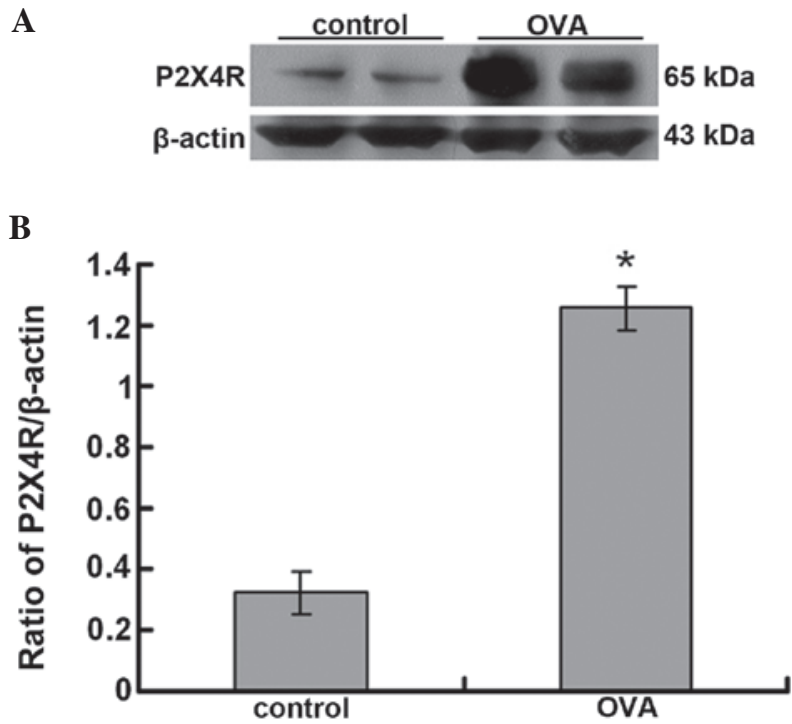

Figure 1. Asthma challenge upregulates the protein expression levels of P2X4R. (A) Expression levels of P2X4R in the lung tissue samples were analyzed using western blot analysis. (B) Optical density values for the protein expression of $\mathrm{P} 2 \mathrm{X} 4 \mathrm{R}$ relative to $\beta$-actin $(\mathrm{n}=4)$. Data are expressed as the mean \pm standard error of the mean. ${ }^{*} \mathrm{P}<0.01$, compared with the control group.

asthmatic mice increased significantly, compared with those in the BALF from the control mice. The increased numbers of inflammatory cells, including eosinophils and lymphocytes, were significantly reduced by the administration of PPAD and 5-BDBD in the asthmatic mice, compared with the numbers found in the untreated asthmatic mice. The changes in the percentages of macrophages showed the opposite results.

$P 2 X 4 R$ is required for collagen deposition in allergic airway challenge in mice. Collagen deposition in airway remodeling was assessed using Masson's trichrome staining of lung histological sections. Collagenous matrix was identified by its characteristic blue color. No obvious collagen fibers were present in the lungs of mice in the control group. However, deposition of collagen fibers was increased around the bronchial airways and vessels in the lungs of the OVA-challenged and ATP-treated mice. By contrast, intervention with PPAD and 5-BDBD significantly reduced collagen deposition (Fig. $4 \mathrm{~A}$ and $\mathrm{B}$ ).

P2X4R is required for goblet cell hyperplasia and mucus production in allergic airway challenge in mice. To assess mucus production and the hyperplasia of goblet cells, lung sections were stained with AB-PAS. In the OVA-challenged mice, bronchial epithelial mucus secretion and goblet cell hyperplasia were clearly observed, as a violet color in the bronchial airways, compared with the control group. The level of goblet cell hyperplasia in the OVA-challenged mice treated with ATP was significantly increased, compared with that in the OVA group. Intervention by PPAD or 5-BDBD significantly reduced goblet cell hyperplasia (Fig. 5A and B).

$P 2 X 4 R$ regulates the expression of $\alpha-S M A$ and PCNA in the asthmatic mouse lung. Western blotting was performed to examine the protein levels of $\alpha$-SMA (Fig. 6A and B) and PCNA (Fig. 7A and B) in each group. The expression levels 


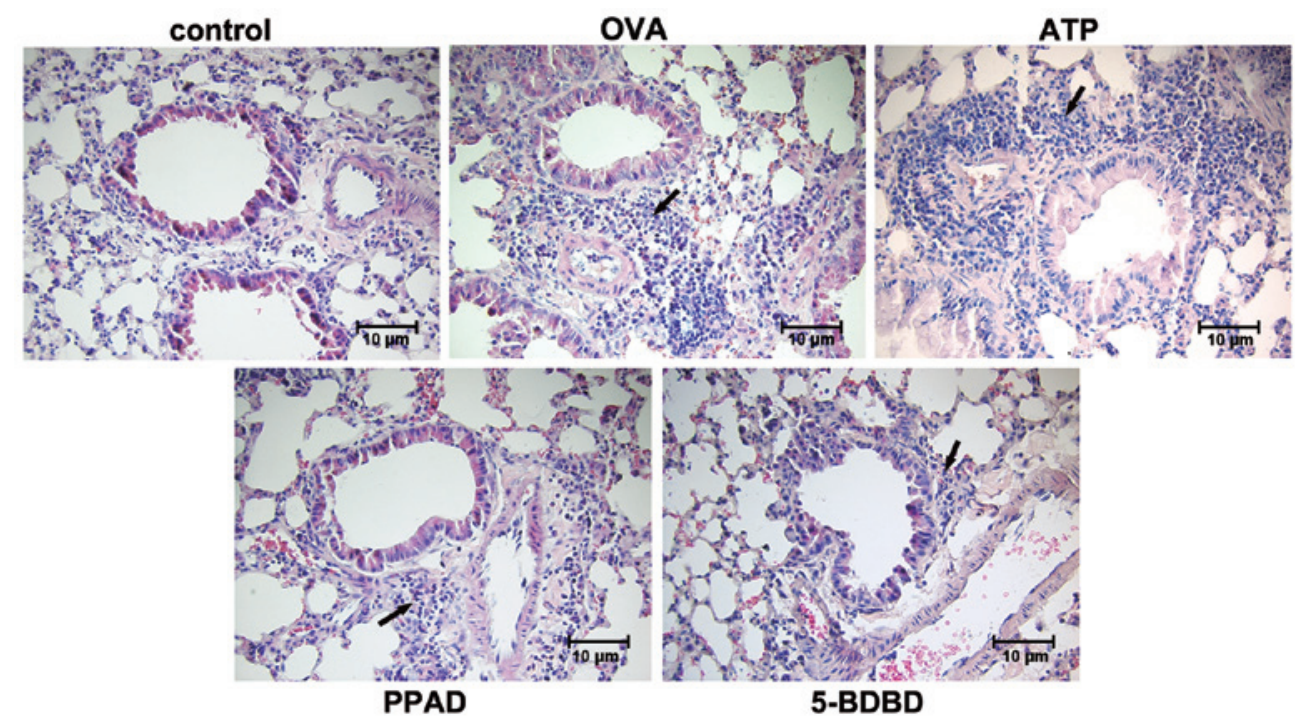

Figure 2. P2X4R contributes to inflammation of the bronchi and lung tissues in allergic airway challenge. Pathological changes in the bronchi and lung tissues were examined following hematoxylin and eosin staining $(n=3)$. Marked inflammatory cell infiltration in the asthmatic mice was aggravated by treatment with ATP, but significantly alleviated by intervention with PPAD and with 5-BDBD. Black arrows indicate areas with clear infiltrated inflammatory cells ATP, adenosine triphosphate; PPAD, phenyl-isopropyl-amine dopes.
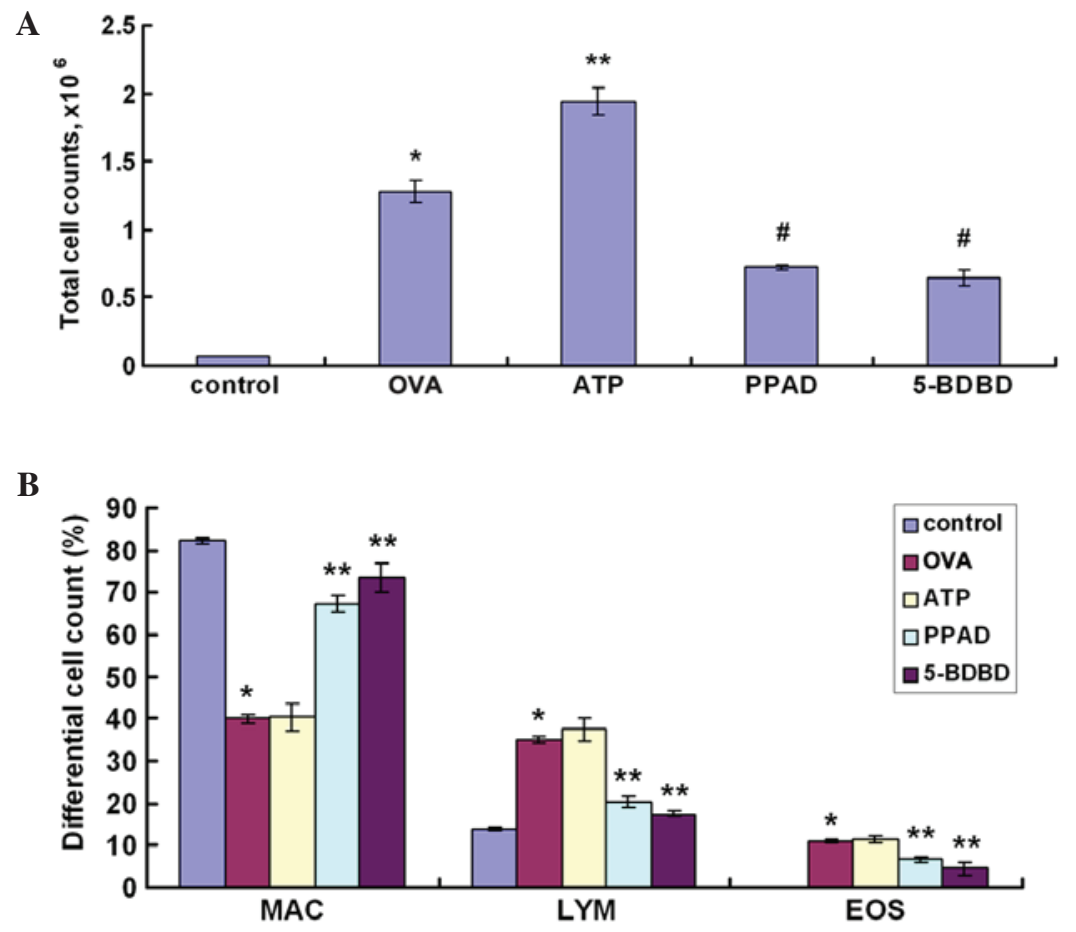

Figure 3. Allergic airway challenge increases the numbers of inflammatory cells. (A) Total cell number. (B) Percentages of macrophages (MAC), lymphocytes $(\mathrm{LYM})$ and eosinophils (EOS). Data are expressed as the mean \pm standard error of the mean. ${ }^{*} \mathrm{P}<0.01$, compared with the control group; ${ }^{* *} \mathrm{P}<0.01$ and ${ }^{\# \mathrm{P}}<0.05$, compared with the OVA group. ATP, adenosine triphosphate; PPAD, phenyl-isopropyl-amine dopes.

of $\alpha$-SMA in the OVA-challenged mice and ATP-treated mice were significantly lower, compared with those in the control mice. In addition, the mice treated with 5-BDBD showed significantly increased protein expression levels of $\alpha$-SMA, compared with the mice in the OVA and ATP groups. However, the mice treated with PPAD showed no significant differences in protein expression, compared with the OVA group. The expression level of PCNA in the OVA-challenged mice and the ATP-treated mice were significantly higher than the level in the control mice. In addition, the mice treated with 5-BDBD showed a significant reduction in the protein expression levels of PCNA, compared with the mice in the OVA and ATP groups. Treatment with PPAD had no significant effects.

\section{Discussion}

Allergic asthma is a chronic airway inflammatory-driven disease, which is characterized by airway 
A

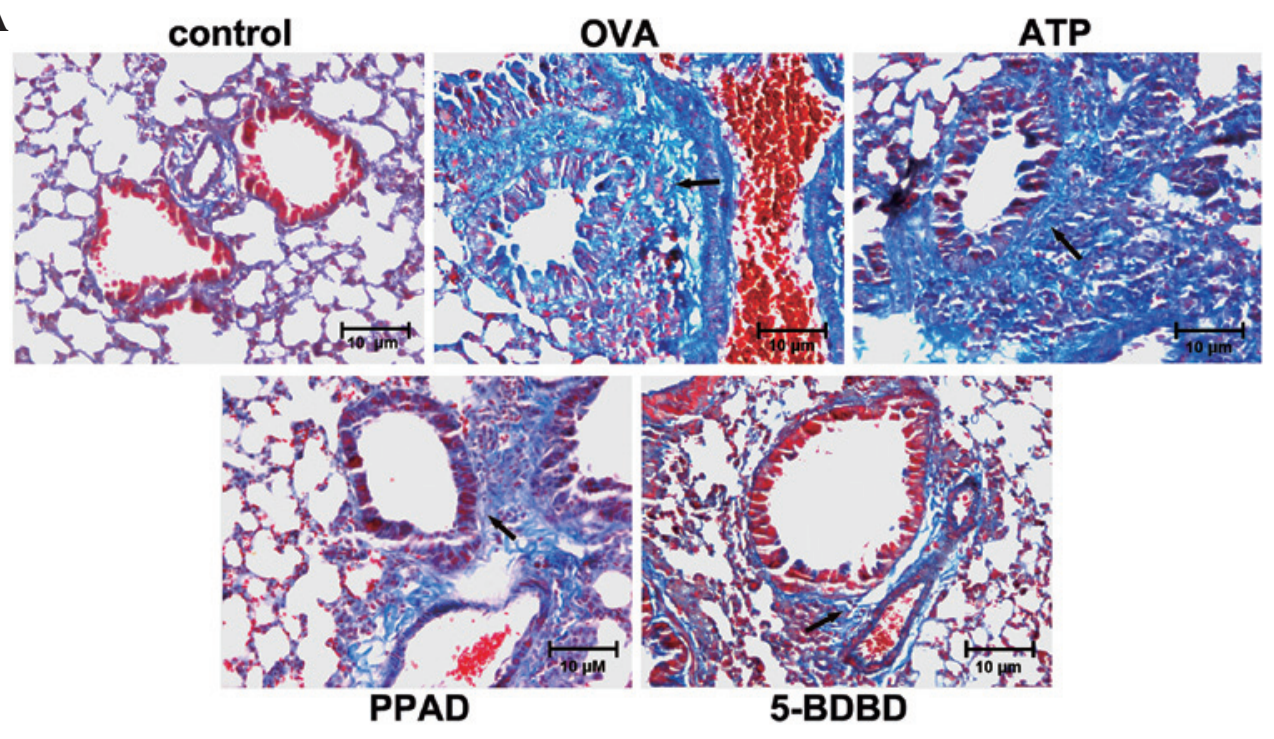

B

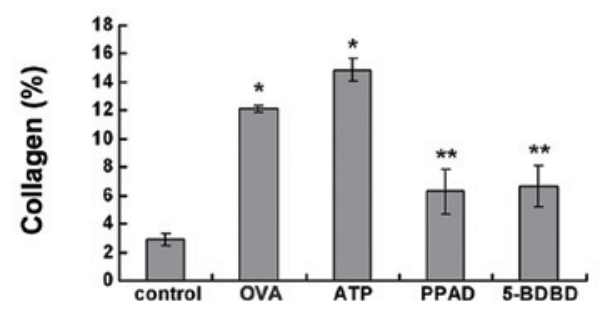

Figure 4. P2X4R is required for collagen deposition in allergic airway challenge. (A) Masson's trichrome staining for examination of collagen deposition in the lungs. Collagen is stained blue. Black arrows indicate areas with collagen deposition. (B) Percentages of collagen, calculated as the $\%$ total area ( $\mathrm{n}=3$ ). Data are expressed as the mean \pm standard error of the mean. ${ }^{*} \mathrm{P}<0.01$, compared with the control group; ${ }^{* *} \mathrm{P}<0.01$, compared with the OVA group. ATP, adenosine triphosphate; PPAD, phenyl-isopropyl-amine dopes.

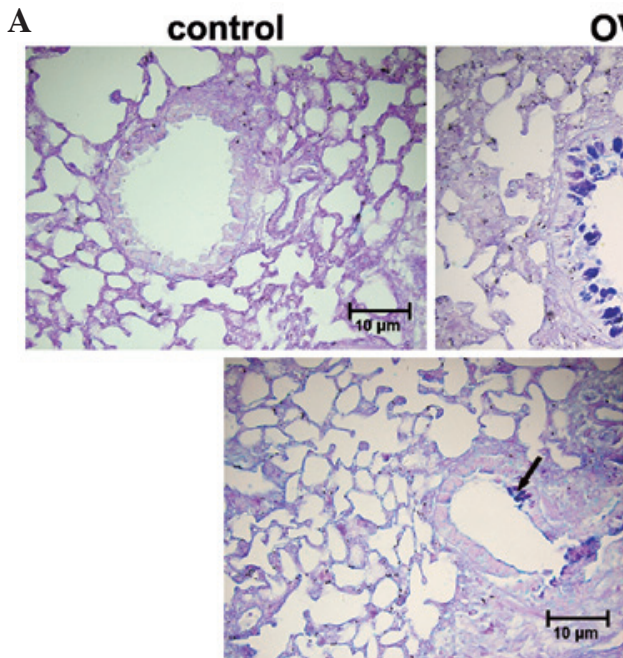

PPAD
OVA
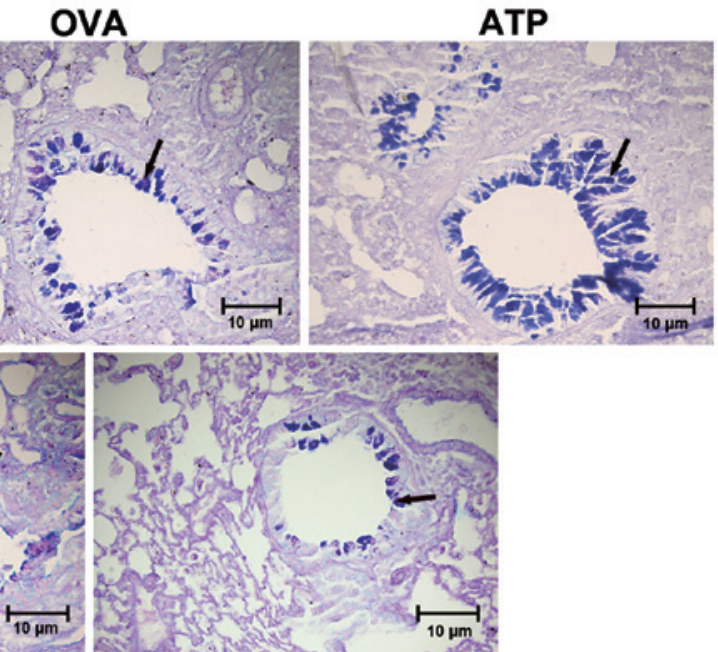

5-BDBD

B

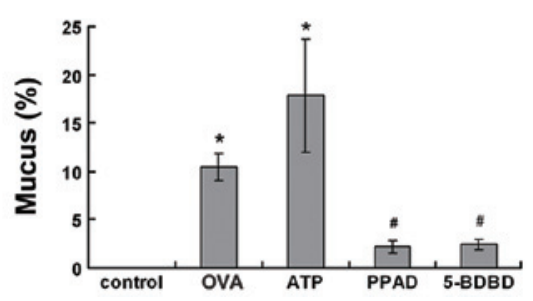

Figure 5. P2X4R is required for goblet cell hyperplasia and mucus production in allergic airway challenge. (A) Alcian blue/periodic acid-Schiff staining for mucus secretion (stained violet). Black arrows indicate areas with goblet cell hyperplasia and mucus production. (B) Percentage of mucus in the total mucus area measured $(\mathrm{n}=3)$. Data are expressed as the mean \pm standard error of the mean. ${ }^{*} \mathrm{P}<0.01$, compared with the control group; ${ }^{*} \mathrm{P}<0.05$, compared with the $\mathrm{OVA}$ group. ATP, adenosine triphosphate; PPAD, phenyl-isopropyl-amine dopes. 


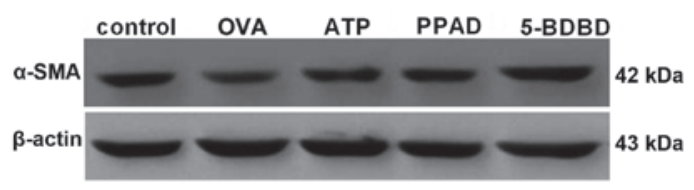

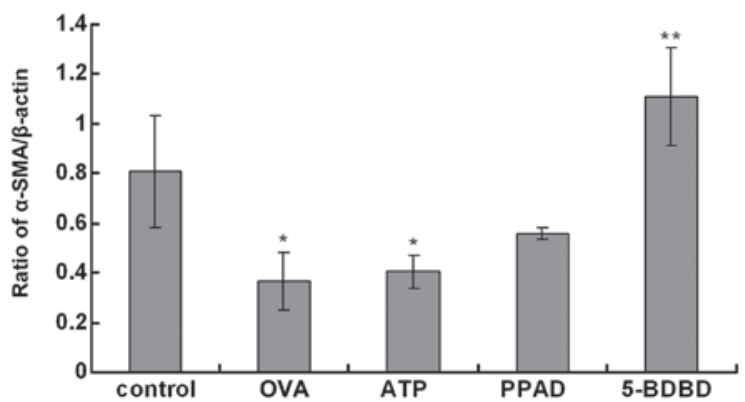

Figure 6. P2X4R regulates the expression of $\alpha$-SMA in the asthmatic mouse lung. (A) Expression of $\alpha$-SMA in the lung tissues. (B) Optical density values for $\alpha$-SMA protein, relative to $\beta$-actin $(n=4)$. Data are expressed as the mean \pm standard error of the mean. ${ }^{*} \mathrm{P}<0.05$, compared with the control group; ${ }^{* *} \mathrm{P}<0.01$, compared with the OVA group. ATP, adenosine triphosphate; PPAD, phenyl-isopropyl-amine dopes; $\alpha$-SMA, $\alpha$-smooth muscle actin.

A

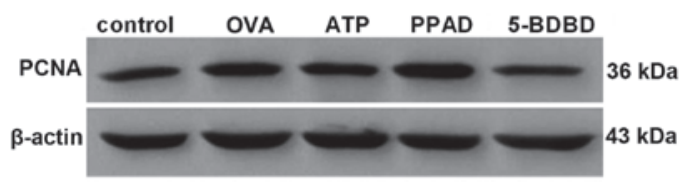

B

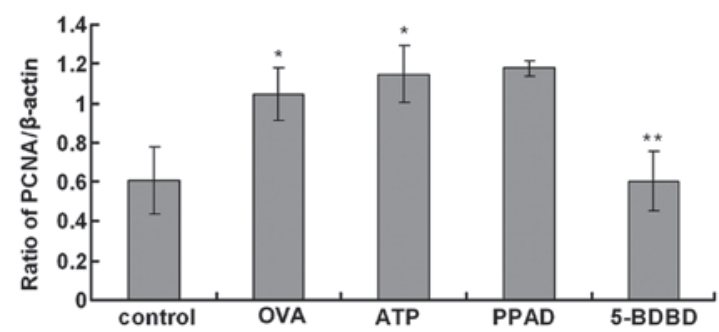

Figure 7. P2X4R regulates the expression of PCNA in the asthmatic mouse lung (A) Expression of PCNA in lung tissues. (B) Optical density values for PCNA protein, relative to $\beta$-actin $(n=4)$. Data are expressed as the mean \pm standard error of the mean. ${ }^{*} \mathrm{P}<0.05$, compared with the control group; ${ }^{* *} \mathrm{P}<0.05$, compared with the OVA group. ATP, adenosine triphosphate; PPAD, phenyl-isopropyl-amine dopes; PCNA, proliferating cell nuclear antigen.

hyper-responsiveness, airway inflammation and varying degrees of smooth muscle cell proliferation, termed airway remodeling (36-38). In the present study, airway inflammation and airway remodeling were examined in allergen-challenged mice. The pathophysiological mechanisms underlying airway remodeling remain to be fully elucidated. Compelling evidence indicates a pathophysiological relevance for ATP, acting via $\mathrm{P} 2$ purinergic receptors, in pain hypersensitivity and peripheral inflammation (39-41). Certain studies have suggested that ATP contributes to the pathophysiology of allergic airway inflammation $(14,16,42)$. In the present study, treatment of OVA-challenged mice with ATP significantly increased OVA-induced inflammation, infiltration, and pathological changes of the bronchi and lung tissues. Increased collagen deposition, goblet cell hyperplasia/mucus production, increased expression levels of PCNA expression, and decreased expression levels of $\alpha$-SMA are indicative of airway remodeling (43-46), and were observed in mice belonging to the OVA-challenged and ATP-treated groups. These results indicated that ATP may enhance airway inflammation and airway remodeling in allergic asthma. However, whether P2X4R is activated in allergic asthma by ATP-mediated signaling has not been determined.

Among the P2XR subtypes, P2X4R is the most widely expressed, which is expressed in blood vessels, the lungs, kidneys and immune cells $(47,48)$. Additionally, P2X4R is involved in regulating blood pressure and vascular remodeling by ATP-induced $\mathrm{Ca} 2^{+}$influx and flow-mediated vasodilatation $(49,50)$. P2X4Rs are also involved in modulating right ventricular hypertrophy, which occurs due to pulmonary hypertension in hypobaric hypoxia (51). Asthma and pulmonary arterial hypertension exhibit three major pathological features: Inflammation, smooth muscle constriction and smooth muscle cell proliferation (52). In the present study, the results demonstrated that treatment with the P2X4R antagonist, 5-BDBD, prevented the development of the airway and pulmonary inflammation, and airway remodeling induced by OVA challenge and OVA challenge coupled with ATP treatment. By contrast, treatment with PPAD showed no significant effect on the expression levels of $\alpha$-SMA or PCNA. These data indicated that ATP-mediated $\mathrm{P} 2 \mathrm{X} 4 \mathrm{R}$ activation, but not $\mathrm{P} 2 \mathrm{X} 1 / 2 / 3 / 5 / 7 \mathrm{R}$ activation, was involved in airway inflammation and airway remodeling in allergic asthma. This suggests that P2X4R is involved in the pathogenesis of asthma via an ATP-mediated signaling pathway. To the best of our knowledge, the present study provides the first indication that $\mathrm{P} 2 \mathrm{X} 4 \mathrm{R}$ signaling is activated in allergic asthma, and contributes to airway inflammation and remodeling.

In conclusion, the results of the present study demonstrated the importance of P2X4R in allergic asthma. ATP-P2X4R signaling contributes to the pathogenesis of allergic asthma in mice. OVA-induced allergic asthma in mice was enhanced by the P2X4R agonist and attenuated by the P2X4R antagonist. The finding suggested that the ATP-P2X4R pathway may not only contribute to airway inflammation, but also to airway remodeling in models of allergic asthma in mice. The exact mechanisms of ATP-P2X4R signaling responsible for asthma pathogenesis requires further investigation. 


\section{Acknowledgements}

This study was supported by the Natural Science Foundation of China (grant no. 81200011) and the Postdoctoral Science Foundation of Heilongjiang Province in China (grant no. LBH-Z12213).

\section{References}

1. Benayoun L and Pretolani M: Airway remodeling in asthma: Mechanisms and therapeutic perspectives. Med Sci (Paris) 19: 319-326, 2003.

2. Uhlík J, Simůnková P, Žaloudíková M, Partlová S, Jarkovský J and Vajner L: Airway wall remodeling in young and adult rats with experimentally provoked bronchial asthma. Int Arch Allergy Immunol 164: 289-300, 2014.

3. Rhee CK, Kim JW, Park CK, Kim JS, Kang JY, Kim SJ, Kim SC, Kwon SS, Kim YK, Park SH and Lee SY: Effect of imatinib on airway smooth muscle thickening in a murine model of chronic asthma. Int Arch Allergy Immunol 155: 243-251, 2011.

4. Cates C: Inhaled corticosteroids in COPD: Quantifying risks and benefits. Thorax 68: 499-500, 2013.

5. Pascual RM and Peters SP: Airway remodeling contributes to the progressive loss of lung function in asthma: An overview. J Allergy Clin Immunol 116: 477-486, 2005.

6. McParland BE, Macklem PT and Pare PD: Airway wall remodeling: Friend or foe? J Appl Physiol (1985) 95: 426-434, 2003.

7. James AL and Wenzel S: Clinical relevance of airway remodelling in airway diseases. Eur Respir J 30: 134-155, 2007.

8. Royce SG and Tang ML: The effects of current therapies on airway remodeling in asthma and new possibilities for treatment and prevention. Curr Mol Pharmacol 2: 169-181, 2009.

9. Raissy HH, Kelly HW, Harkins $\mathbf{M}$ and Szefler SJ: Inhaled corticosteroids in lung diseases. Am J Respir Crit Care Med 187: 798-803, 2013.

10. Tagaya E and Tamaoki J: Mechanisms of airway remodeling in asthma. Allergol Int 56: 331-340, 2007.

11. Warner SM and Knight DA: Airway modeling and remodeling in the pathogenesis of asthma. Curr Opin Allergy Clin Immunol 8: 44-48, 2008.

12. Roy SG, Nozaki Y and Phan SH: Regulation of alpha-smooth muscle actin gene expression in myofibroblast differentiation from rat lung fibroblasts. Int J Biochem Cell Biol 33: 723-734, 2001 .

13. Stumm CL, Halcsik E, Landgraf RG, Camara NO, Sogayar MC and Jancar S: Lung remodeling in a mouse model of asthma involves a balance between tgf- $\beta 1$ and BMP-7. PloS One 9: e95959, 2014.

14. Kesavan R, Potunuru UR, Nastasijević B, T A, Joksić G and Dixit M: Inhibition of vascular smooth muscle cell proliferation by gentiana lutea root extracts. PloS One 8: e61393, 2013.

15. Zhao L, Wu J, Zhang X, Kuang H, Guo Y and Ma L: The effect of shenmai injection on the proliferation of rat airway smooth muscle cells in asthma and underlying mechanism. BMC Complement Altern Med 13: 221, 2013.

16. Idzko M, Hammad H, van Nimwegen M, Kool M, Willart MA, Muskens F, Hoogsteden HC, Luttmann W, Ferrari D, Di Virgilio F, et al: Extracellular atp triggers and maintains asthmatic airway inflammation by activating dendritic cells. Nat Med 13: 913-919, 2007.

17. Khakh BS and North RA: P2x receptors as cell-surface ATP sensors in health and disease. Nature 442: 527-532, 2006.

18. Lommatzsch M, Cicko S, Müller T, Lucattelli M, Bratke K, Stoll P, Grimm M, Dürk T, Zissel G, Ferrari D, et al: Extracellular adenosine triphosphate and chronic obstructive pulmonary disease. Am J Respir Crit Care Med 181: 928-934, 2010

19. Müller T, Vieira RP, Grimm M, Dürk T, Cicko S, Zeiser R Jakob T, Martin SF, Blumenthal B, Sorichter S, et al: A potential role for $\mathrm{p} 2 \times 7 \mathrm{r}$ in allergic airway inflammation in mice and humans. Am J Respir Cell Mol Biol 44: 456-464, 2011.

20. Di Virgilio F: Purines, purinergic receptors and cancer. Cancer Res 72: 5441-5447, 2012.

21. Aymeric L, Apetoh L, Ghiringhelli F, Tesniere A, Martins I, Kroemer G, Smyth MJ and Zitvogel L: Tumor cell death and ATP release prime dendritic cells and efficient anticancer immunity. Cancer Res 70: 855-858, 2010.
22. la Sala A, Ferrari D, Corinti S, Cavani A, Di Virgilio F and Girolomoni G: Extracellular ATP induces a distorted maturation of dendritic cells and inhibits their capacity to initiate Th1 responses. J Immunol 166: 1611-1617, 2001.

23. Tanaka J, Murate M, Wang CZ, Seino S and Iwanaga T: Cellular distribution of the P2X4 ATP receptor mRNA in the brain and non-neuronal organs of rats. Arch Histol Cytol 59: 485-490, 1996.

24. Weinhold K, Krause-Buchholz U, Rödel G, Kasper M and Barth $\mathrm{K}$ : Interaction and interrelation of $\mathrm{P} 2 \mathrm{X} 7$ and $\mathrm{P} 2 \mathrm{X} 4$ receptor complexes in mouse lung epithelial cells. Cell Mol Life Sci 67: 2631-2642, 2010.

25. Barth K and Kasper M: Membrane compartments and purinergic signalling: Occurrence and function of $\mathrm{P} 2 \mathrm{X}$ receptors in lung. FEBS J 276: 341-353, 2009.

26. Wareham K, Vial C, Wykes RC, Bradding P and Seward EP: Functional evidence for the expression of P2X1, P2X 4 and P2X7 receptors in human lung mast cells. British journal of pharmacology 157: 1215-1224, 2009.

27. Inoue K: The function of microglia through purinergic receptors: Neuropathic pain and cytokine release. Pharmacol Ther 109: 210-226, 2006.

28. Ulmann L, Hirbec $\mathrm{H}$ and Rassendren F: P2X4 receptors mediate PGE2 release by tissue-resident macrophages and initiate inflammatory pain. EMBO J 29: 2290-2300, 2010.

29. Tsuda M, Kuboyama K, Inoue T, Nagata K, Tozaki-Saitoh H and Inoue $\mathrm{K}$ : Behavioral phenotypes of mice lacking purinergic $\mathrm{P} 2 \mathrm{X} 4$ receptors in acute and chronic pain assays. Mol Pain 5: 28 2009.

30. Jakobsson PJ: Pain: How macrophages mediate inflammatory pain via ATP signaling. Nat Rev Rheumatol 6: 679-681, 2010.

31. Shen HH, Xu F, Zhang GS, Wang SB and Xu WH: CCR3 monoclonal antibody inhibits airway eosinophilic inflammation and mucus overproduction in a mouse model of asthma. Acta Pharmacol Sin 27: 1594-1599, 2006.

32. Vanacker NJ, Palmans E, Kips JC and Pauwels RA: Fluticasone inhibits but does not reverse allergen-induced structural airway changes. Am J Respir Crit Care Med 163: 674-679, 2001.

33. Wu T, Dai M, Shi XR, Jiang ZG and Nuttall AL: Functional expression of $\mathrm{P} 2 \mathrm{X} 4$ receptor in capillary endothelial cells of the cochlear spiral ligament and its role in regulating the capillary diameter. Am J Physiol Heart Circ Physiol 301: H69-H78, 2011.

34. Krugel U, Schraft T, Regenthal R, Illes P and Kittner H: Purinergic modulation of extracellular glutamate levels in the nucleus accumbens in vivo. Int J Dev Neurosci 22: 565-570, 2004.

35. Chen K, Zhang J, Zhang W, Zhang J, Yang J, Li K and He Y: ATP-P2X4 signaling mediates NLRP3 inflammasome activation: A novel pathway of diabetic nephropathy. Int J Biochem Cell Biol 45: 932-943, 2013.

36. Mauad T, Bel EH and Sterk PJ: Asthma therapy and airway remodeling. J Allergy Clin Immunol 120: 997-1009, 2007.

37. Broide DH: Immunologic and inflammatory mechanisms that drive asthma progression to remodeling. J Allergy Clin Immunol 121: 560-570, 2008.

38. Bousquet J, Jeffery PK, Busse WW, Johnson M and Vignola AM: Asthma. From bronchoconstriction to airways inflammation and remodeling. Am J Respir Crit Care Med 161: 1720-1745, 2000.

39. Di Virgilio F: Purinergic signalling between axons and microglia. Novartis Found Symp 276: 253-258, 2006.

40. Donnelly-Roberts D, McGaraughty S, Shieh CC, Honore P and Jarvis MF: Painful purinergic receptors. J Pharmacol Exp Ther 324: 409-415, 2008.

41. Jarvis MF: The neural-glial purinergic receptor ensemble in chronic pain states. Trends Neurosci 33: 48-57, 2010.

42. Riteau N, Gasse P, Fauconnier L, Gombault A, Couegnat M, Fick L, Kanellopoulos J, Quesniaux VF, Marchand-Adam S, Crestani B, et al: Extracellular ATP is a danger signal activating $\mathrm{P} 2 \mathrm{X} 7$ receptor in lung inflammation and fibrosis. Am J Respir Crit Care Med 182: 774-783, 2010

43. Chiappara G, Gagliardo R, Siena A, Bonsignore MR, Bousquet J Bonsignore G and Vignola AM: Airway remodelling in the pathogenesis of asthma. Curr Opin Allergy Clin Immunol 1: 85-93, 2001.

44. Kudo M, Ishigatsubo Y and Aoki I: Pathology of asthma. Front Microbiol 4: 263, 2013.

45. Moir LM, Leung SY, Eynott PR, McVicker CG, Ward JP, Chung KF and Hirst SJ: Repeated allergen inhalation induces phenotypic modulation of smooth muscle in bronchioles of sensitized rats. Am J Physiol Lung Cell Mol Physiol 284: L148-L159, 2003. 
46. Labonté I, Hassan M, Risse PA, Tsuchiya K, Laviolette M, Lauzon AM and Martin JG: The effects of repeated allergen challenge on airway smooth muscle structural and molecular remodeling in a rat model of allergic asthma. Am J Physiol Lung Cell Mol Physiol 297: L698-L705, 2009.

47. Kim MJ, Turner CM, Hewitt R, Smith J, Bhangal G, Pusey CD Unwin RJ and Tam FW: Exaggerated renal fibrosis in P2X4 receptor-deficient mice following unilateral ureteric obstruction. Nephrol Dial Transplant 29: 1350-1361, 2014.

48. Soto F, Garcia-Guzman M, Gomez-Hernandez JM, Hollmann M, Karschin C and Stühmer W: P2X4: An ATP-activated ionotropic receptor cloned from rat brain. Proc Natl Acad Sci USA 93: 3684-3688, 1996.
49. Kellner R, Matzkies F, Sailer D and Berg G: Potassium substitution in fasting. Z Ernahrungswiss 16: 73-76, 1977 (In German).

50. Yamamoto K, Sokabe T, Matsumoto T, Yoshimura K, Shibata M, Ohura N, Fukuda T, Sato T, Sekine K, Kato S, et al: Impaired flow-dependent control of vascular tone and remodeling in P2X4-deficient mice. Nat Med 12: 133-137, 2006.

51. Ohata Y, Ogata S, Nakanishi K, Kanazawa F, Uenoyama M, Hiroi S, Tominaga S and Kawai T: Expression of P2X4R mRNA and protein in rats with hypobaric hypoxia-induced pulmonary hypertension. Circ J 75: 945-954, 2011.

52. Said SI, Hamidi SA and Gonzalez Bosc L: Asthma and pulmonary arterial hypertension: Do they share a key mechanism of pathogenesis? Eur Respir J 35: 730-734, 2010 